\title{
Pemanfaatan Teknologi dan Pengembangan Usaha Damar Keripik
}

\author{
* Luh Made Yulyantari, I Gede Putu Adhitya Prayoga \\ Fakultas Informatika dan Komputer Institut Teknologi dan Bisnis STIKOM Bali \\ Jln Raya Puputan No 86 Denpasar \\ *E-mail : yulyantari@stikom-bali.ac.id
}

DOI: https://doi.org/10.21107/pangabdhi.v6i2.7585

Naskah diterima 27 Juli 2020, Revisi 11 Agustus 2020, Terbit 29 Oktober 2020

\begin{abstract}
Abstrak
Keripik kacang merupakan salah satu produksi industri rumah tangga makanan ringan yang sangat familiar dan banyak terdapat di pasaran. Salah satu industri rumah tangga atau Usaha Mikro Kecil Menengah (UMKM) yang bergerak di bidang tersebut adalah Damar Keripik. Damar Keripik hanya memiliki satu jenis variasi produk yang dijual. Permasalahan yang ditemukan pada mitra adalah pada aspek produksi, pemasaran, dan aspek manajemen. Pada aspek produksi terdapat beberapa permasalahan yaitu, segel kemasan yang masih menggunakan alat yang konvensional, serta alat produksi yang masih kurang. Pada aspek pemasaran, belum adanya label kemasan yang mencantumkan indentitas mitra di dalamnya dan belum adanya variasi ukuran dalam pengemasan. Pada aspek manajemen, kondisi administrasi pencatatan data penjualan yang lemah, seringkali menjadi penyebab sulitnya mengajukan kredit ke pihak ketiga. Lemahnya administrasi pencatatan data penjualan mengakibatkan sulitnya melakukan penilaian kelayakan. Berdasarkan permasalahan tersebut, maka dilaksanakan kegiatan melalui Program Kemitraan Masyarakat (PKM) berupa dua jenis kegiatan. Kegiatan pertama, yaitu membantu proses produksi, dengan pemberian tambahan alat produksi dan pembuatan label kemasan. Kegiatan kedua berupa kegiatan untuk membantu bagian manajemen, yaitu berupa pelatihan pencatatan penjualan. Secara keseluruhan hasil monitoring dan evaluasi dari mitra, 20\% menyatakan cukup, 26\% menyatakan baik, dan 54\% menyatakan baik sekali.
\end{abstract}

Kata Kunci: keripik kacang, excel, pencatatan penjualan

\begin{abstract}
Peanut chips are a very familiar and widely available household snack industry production on the market. One of the household industries or Micro, Small and Medium Enterprises (UMKM) engaged in the field is Damar Keripik. Damar Keripik only has one type of product variation that is sold. The problems found in partners are in the aspects of production, marketing, and management aspects. In the aspect of production there are several problems, namely, packaging seals that still use conventional tools, and production equipment that is still lacking. In the marketing aspect, there is no packaging label that includes the partner identity in it and there is no variation in packaging size. In the management aspect, the administrative conditions for recording weak sales data often lead to difficulties in applying for credit to third parties. The weak administration of recording sales data has made it difficult to conduct a feasibility assessment. Based on these problems, activities were carried out through the Community Partnership Program (PKM) in the form of two types of activities. The first activity, which is helping the production process, by providing additional production equipment and making packaging labels. The second activity is in the form of activities to assist the management section, namely in the form of sales registration training. Overall monitoring and evaluation results from partners, 20\% said it was enough, 26\% said it was good, and $54 \%$ said it was very good.
\end{abstract}

Keywords: peanut chips, excel, recording of sales

\section{PENDAHULUAN}

Keripik adalah salah satu makanan ringan yang dapat digunakan sebagai makanan tambahan. Terdapat beragam jenis keripik, salah satunya keripik kacang atau sering dikenal sebagai Peyek Kacang. Keripik Kacang terbuat dari adonan tepung yang dicampur dengan kacang tanah atau jenis kacang lainnya, seperti pada Gambar 1.

Keripik kacang merupakan salah satu produksi industri rumah tangga makanan ringan yang sangat familiar dan banyak terdapat di 
pasaran. Salah satu industri rumah tangga atau Usaha Mikro Kecil Menengah (UMKM) yang bergerak di bidang tersebut adalah Damar Keripik. Usaha yang dijalankan masih tergolong kecil dengan omset mencapai 10 juta/bulan. Usaha tersebut berlokasi di daerah Pemogan, Denpasar dijalankan oleh tiga orang, dengan dua orang sebagai pegawai.

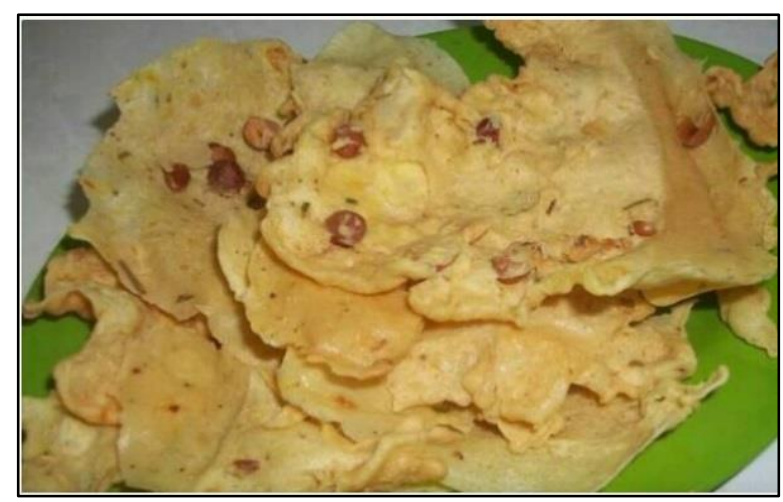

Gambar 1. Keripik Kacang

Damar Keripik hanya memiliki satu jenis variasi produk yang dijual dengan harga 10.000/kemasan. Proses produksi keripik menggunakan penggorengan yang berjumlah dua buah. Pengemasan produk menggunakan alat bantu berupa lilin untuk menutup kemasan. Proses pengemasan dapat dilihat pada Gambar 2. Produk dikemas menggunakan plastik tanpa label kemasan.

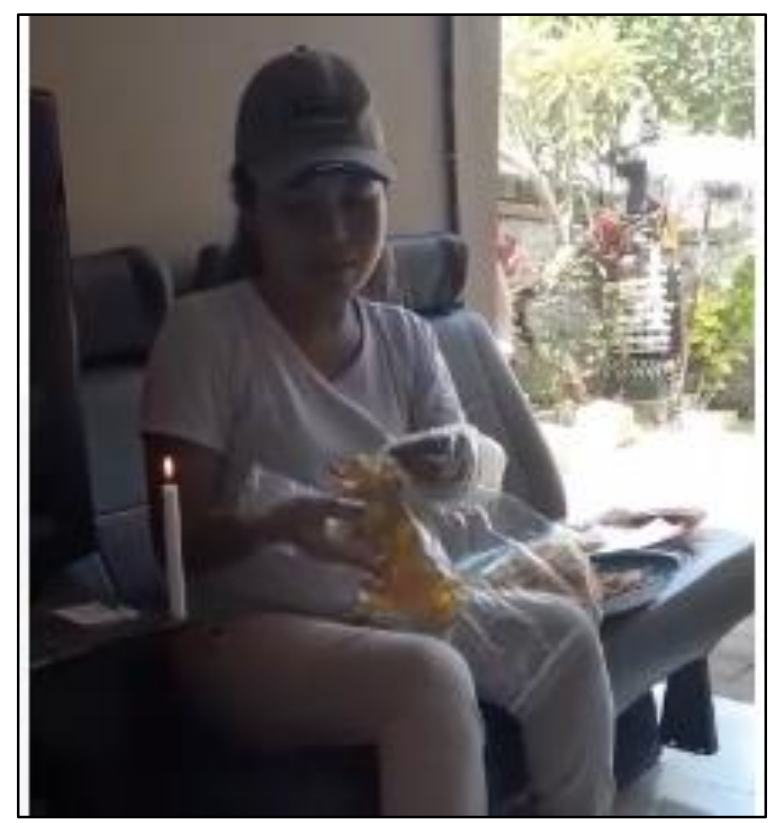

Gambar 2. Proses Pengemasan

Produk dipasarkan kepada pedagangpedagang kecil di sekitar tempat produksi. Hasil penjualan tercatat menggunakan pembukuan tanpa memanfaatkan teknologi yang dimiliki oleh pemilik usaha. Pemilik usaha memiliki satu perangkat komputer yang digunakan oleh salah satu anggota keluarganya yang sedang menempuh pendidikan di Sekolah Menengah Atas. Pemanfaatan teknologi yang masih minim memperlambat pengembangan usaha mitra, karena manajemen administrasi terutama administrasi pencatatan data penjualan yang kurang lengkap.

Berdasarkan uraian sebelumnya, maka permasalahan yang ditemukan pada mitra adalah pada aspek produksi, aspek pemasaran, dan aspek manajemen. Pada aspek produksi terdapat beberapa permasalahan yaitu, segel kemasan yang masih menggunakan alat yang konvensional, serta alat produksi yang masih kurang. Pada aspek pemasaran, belum adanya label kemasan yang mencantumkan indentitas mitra di dalamnya dan belum adanya variasi ukuran dalam pengemasan.

Pada aspek manajemen, kondisi administrasi pencatatan data penjualan yang lemah, seringkali menjadi penyebab sulitnya mengajukan kredit ke pihak ketiga, sebab para investor baru mau menanamkan uang jika terjamin keamanannya. Lemahnya administrasi pencatatan data penjualan mengakibatkan sulitnya melakukan penilaian kelayakan.

Berdasarkan permasalahan tersebut, maka dilaksanakan kegiatan melalui Program Kemitraan Masyarakat (PKM) berupa dua jenis kegiatan. Kegiatan pertama, yaitu membantu proses produksi, dengan pemberian tambahan alat produksi, label kemasan. Kegiatan kedua berupa kegiatan untuk membantu bagian manajemen, yaitu berupa pelatihan pencatatan data penjualan

\section{METODE}

Kegiatan pengabdian masyarakat pelatihan dan penyuluhan ini ditawarkan untuk memberikan solusi bagi permasalahan yang telah dijabarkan sebelumnya. Pendekatan yang ditawarkan bagi realisasi program pengabdian masyarakat pelatihan dan penyuluhan ini adalah model pemberdayaan para staf Damar Keripik dengan langkah-langkah sebagai berikut:

1) Tahap Persiapan;

Persiapan dilakukan dengan survei ke lapangan dan wawancara langsung.

2) Tahap Perencanaan Kegiatan;

Rencana kegiatan yang dilaksanakan meliputi: 
a. Pemberian alat bantu produksi berupa alat produksi utama dan alat pengemasan.

b. Pembuatan desain label kemasan

c. Kegiatan pelatihan penggunaan program Excel, yaitu memberikan dasar-dasar cara pencatatan penjualan.

3) Tahap Pelaksanaan Kegiatan;

Pelaksanaan kegiatan dibagi menjadi dua tahap. Tahap pertama pemberian bantuan alat produksi dan label kemasan. Tahap kedua pemberian pelatihan penggunaan program Excel.

4) Tahap Evaluasi;

Evaluasi dilakukan dengan penyebaran kuesioner.

\section{HASIL DAN PEMBAHASAN \\ Pelaksanaan Kegiatan Pertama}

Kegiatan pertama dalam pengabdian masyarakat ini meliputi dua hal, yaitu penambahan asset produksi dan pembuatan desain label kemasan. Melalui kegiatan pengabdian masyarakat pelatihan dan penyuluhan ini ditawarkan solusi bagi permasalahan-permasalahan yang telah dijabarkan sebelumnya. Pendekatan yang ditawarkan bagi realisasi program pengabdian masyarakat pelatihan dan penyuluhan ini adalah model pemberdayaan para staf Damar Keripik dengan langkah-langkah sebagai berikut:

\section{1) Tahap Persiapan;}

a. Melakukan survei alat produksi yang dibutuhkan oleh mitra. Survei dilakukan secara daring dan dibantu oleh anggota pelaksana pengabdian. Terdapat dua alat yang dibutuhkan berdasarkan permasalahan yang telah dijabarkan sebelumnya, yaitu hand sealer dan alat produksi utama berupa alat penggorengan.

b. Melakukan wawancara kepada mitra mengenai desain kemasan yang dibutuhkan.

2) Tahap Perencanaan;

a. Penambahan asset produksi, berupa hand sealer dan penggorengan.

b. Pembuatan desain label kemasan.

3) Tahap Pelaksanaan

a. Memberikan penambahan asset produksi berupa pemberian hand sealer dan alat penggorengan. Penyerahan bantuan alat produksi dapat dilihat pada Gambar 3. b. Pemberian desain label kemasan yang siap untuk dicetak dan digunakan pada kemasan, seperti yang terlihat pada Gambar 4.

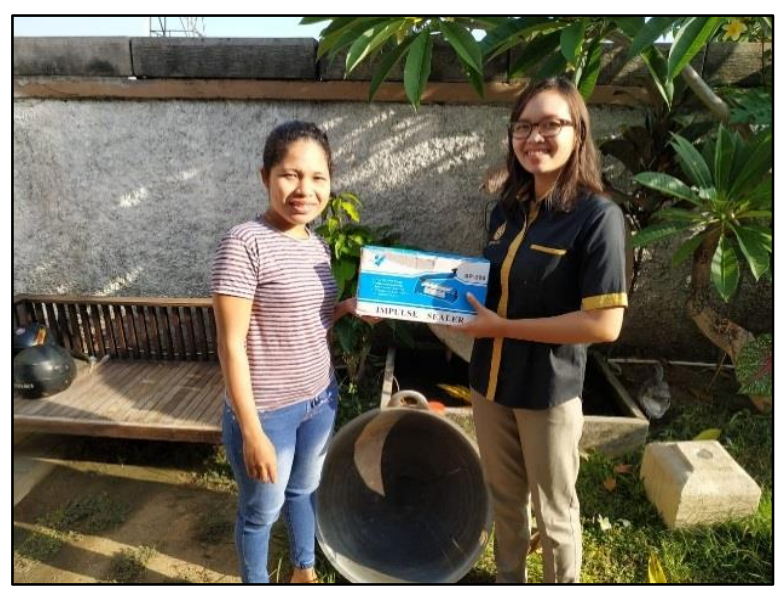

Gambar 3. Penyerahan Bantuan Alat Produksi

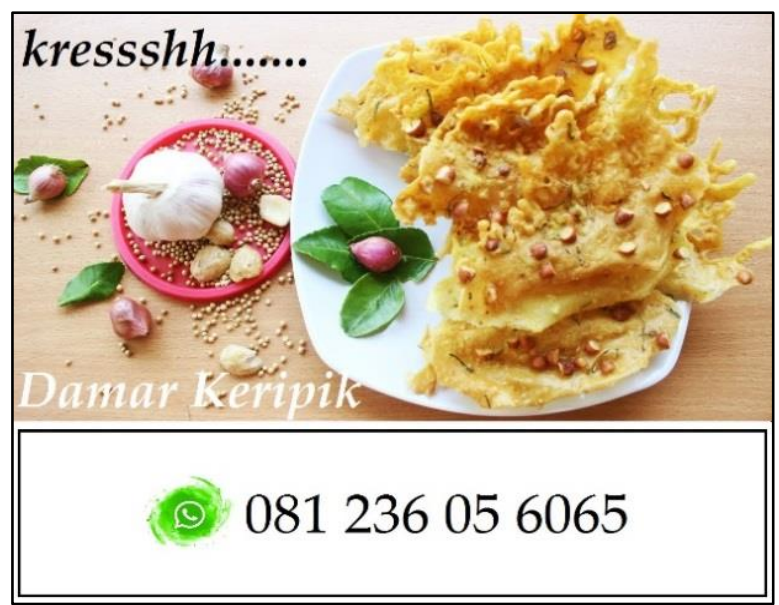

Gambar 4. Desain label kemasan

\section{Pelaksanaan Kegiatan Kedua}

Kegiatan kedua dalam pengabdian kepada masyarakat adalah pelaksanaan pelatihan pencatatan data penjualan pada Microsoft Excel. Kegiatan pengabdian tahap kedua merupakan kelanjutan dari kegiatan pengabdian sebelumnya yang telah selesai dilaksanakan pada akhir Tahun 2019. Terdapat kendala dalam pelaksanaan pengabdian di tengah Pandemi yang terjadi saat ini, yaitu kegiatan pelatihan yang awalnya direncanakan bertatap muka langsung, diganti bentuk pelaksanaannya menjadi bentuk daring. Program pengabdian masyarakat pelatihan dan penyuluhan ini adalah model pemberdayaan para staf Damar Keripik dengan langkah-langkah sebagai berikut:

\section{1) Tahap Perencanaan}

Perencanaan kegiatan pelatihan pencatatan data penjualan menggunakan Micosoft Excel dilakukan dengan dua tahapan utama, yaitu: 
a. Penyusunan Modul dan dokumen pelatihan. Penyusunan modul dibantu oleh kedua anggota pelaksana pengabdian menggunakan beberapa referensi (Lee, 2016). Modul diletakkan pada penyimpanan online untuk mempermudah mitra melakukan akses dokumen.

b. Komunikasi dengan mitra dan persiapan pelatihan secara daring.

Pelaksanaan pelatihan disepakati untuk dilaksanakan pada Tanggal 2 Juni 2020 Pukul 09.00 WITA. Pelaksanaan pelatihan secara daring membuat mitra harus mempelajari penggunaan aplikasi video conference dan meeting untuk memudahkan proses pelatihan secara daring. Aplikasi yang digunakan dalam pelatihan ini adalah Zoom (Zoom, 2020). Sebelum jadwal pelatihan pencatatan data menggunakan Microsoft Excel dilakukan, maka tahapan sebelumnya adalah memberikan pelatihan singkat mengenai cara penggunaan aplikasi Zoom. Tahapan ini berupa uji coba singkat penggunaan aplikasi Zoom, yaitu berupa pengenalan beberapa fitur yang dapat digunakan pada saat meeting.

\section{2) Tahap Pelaksanaan}

Pelaksanaan pelatihan dilakukan secara daring dengan dihadiri oleh salah satu karyawan Damar Keripik. Waktu pelaksanaan terlambat 30 Menit dari jadwal yang seharusnya, karena terkendala koneksi. Pelatihan dimulai pukul 09.30 dan berlangsung selama kurang lebih 50 Menit. Hasil rekaman pelaksanaan pelatihan dapat dilihat pada tautan berikut: https://bit.ly/RekamanPelatihanLMY.

\section{Evaluasi Kegiatan}

Evaluasi kegiatan dilakukan melalui kuisioner. Pertanyaan yang diajukan terkait pelaksanaan kegiatan dan pembicara. Berdasarkan hasil jawaban mitra, secara keseluruhan hasil penilaian kegiatan dari mitra, $45 \%$ menyatakan kegiatan pengabdian masyarakat memuaskan. Monitoring dan evaluasi kegiatan juga dilakukan menggunakan kuisioner. Secara keseluruhan hasil monitoring dan evaluasi dari mitra, 20\% menyatakan cukup, 26\% menyatakan baik, dan $54 \%$ menyatakan baik sekali. Grafik monitoring dan evaluasi kegiatan dapat dilihat pada Gambar 5. Selain itu, mitra menyatakan beberapa hal berikut.
a. Kegiatan pengabdian sudah baik.

b. Pelatihan tetap berjalan secara daring meskipun ada pandemi.

c. Penambahan asset produksi diperbanyak.

d. Penjelasan mengenai penggunaan label kemasan diperbanyak.

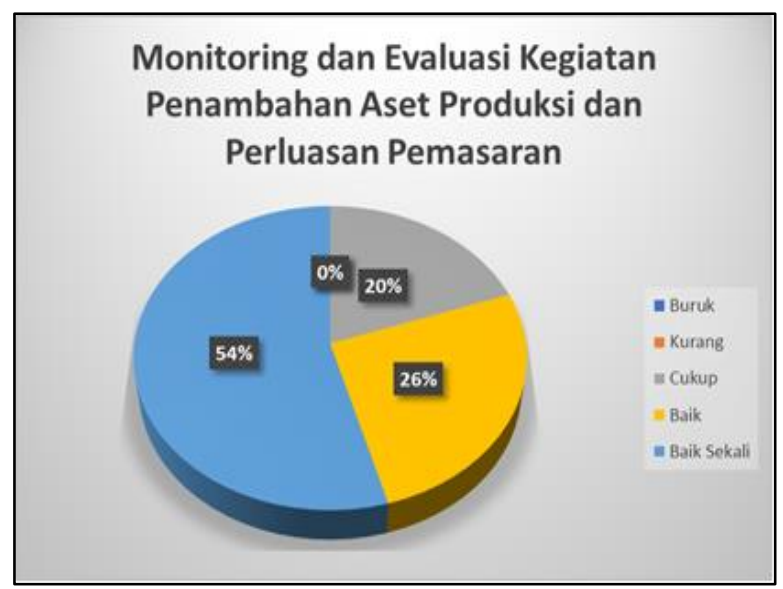

Gambar 5. Hasil Kuisioner Monitoring

Oleh karena terbatasnya waktu dan dana dalam pelaksanaan Program Kemitraan Masyarakat pada kegiatan saat ini, maka terdapat program lanjutan yang direncanakan, antara lain:

1. Bidang Pemasaran, yaitu mengganti kemasan plastik menjadi kemasan yang ramah lingkungan. Hal ini sesuai dengan program pemerintah yang sudah dihimbau melalui Peraturan Walikota Denpasar No.36/2018 tentang Pengurangan Penggunaan Kantong Plastik (Denpasar, 2018) dan Peraturan Gubernur Bali No.97/2018 tentang Pembatasan Timbulan Sampah Plastik Sekali Pakai (Bali, 2018).

2. Bidang Produksi, yaitu berupa penambahan alat penyimpanan yang memiliki tutup yang kedap udara, sehingga produk yang tidak terkemas masih memiliki kualitas yang baik.

\section{KESIMPULAN}

Terdapat beberapa kesimpulan yang dapat diambil dari pelaksanaan pengabdian masyarakat ini, yaitu:

1. Hasil dari pengabdian masyarakat adalah berupa penambahan asset alat produksi, desain label kemasan Damar Keripik, penambahan kompetensi mitra dalam pencatatan data menggunakan Microsoft Excel, serta modul pelatihan.

2. Secara keseluruhan hasil monitoring dan evaluasi dari mitra, 20\% menyatakan cukup, $26 \%$ menyatakan baik, dan $54 \%$ menyatakan baik sekali. 
Berdasarkan pengabdian yang telah dilaksanakan, maka terdapat beberapa rekomendasi yang dapat diberikan, yaitu:

1. Dalam pelaksanaan kegiatan pengabdian selanjutnya sebaiknya fokus terhadap diversifikasi produk.

2. Melanjutkan kegiatan pelatihan berikutnya yang terkait dengan pelatihan manajemen pencatatan data penjualan

\section{UCAPAN TERIMA KASIH}

Terima kasih kepada Damar Keripik atas kerjasama yang sangat baik dalam pelaksanaan pengabdian masyarakat ini dan kepada ITB STIKOM Bali yang mendukung terlaksananya kegiatan pengabdian secara baik dan lancar dengan memberikan dukungan berupa dana pengabdian.

\section{DAFTAR PUSTAKA}

Bali, G. (2018, Desember 21). Peraturan Gubernur Bali Nomor 97 Tahun 2018
Tentang PEMBATASAN TIMBULAN

SAMPAH PLASTIK SEKALI PAKAI. Diambil kembali dari JDIH Pemerintah Provinsi Bali: https://jdih.baliprov.go.id/produkhukum/peraturan/abstrak/24688

Denpasar, W. (2018, Oktober 4). PERATURAN WALIKOTA NOMOR 36 TAHUN 2018 TENTANG PENGURANGAN PENGGUNAAN KANTONG PLASTIK. Diambil kembali dari JDIH Kota Denpasar: https://jdih.denpasarkota.go.id/produkhukum/peraturan-perundangundangan/perwali $/ 446$

Lee, C. (2016). Belajar Microsoft Excel - Step by Step. Jakarta: Elex Media Komputindo.

Lee, C. (2016). PowerTips Microsoft Excel Terbaru dan Terbaik. Jakarta: Elex Media Komputindo.

Zoom. (2020, Juni 1). Join a Meeting. Diambil kembali dari Zoom: https://zoom.us/join 
2 Jurnal Pangabdhi 